\title{
A 350 year drought reconstruction from Alpine tree ring stable isotopes
}

\author{
Anne Kress, ${ }^{1}$ Matthias Saurer, ${ }^{1}$ Rolf T. W. Siegwolf, ${ }^{1}$ David C. Frank, ${ }^{2}$ Jan Esper, ${ }^{3}$ \\ and Harald Bugmann ${ }^{4}$ \\ Received 18 June 2009; revised 30 September 2009; accepted 8 December 2009; published 22 May 2010.
}

[1] Climate reconstructions based on stable isotopes in tree rings rely on the assumption that fractionation-controlling processes are strongly linked to meteorological variables.

In this context, we investigated the climate sensitivity of 350 years of carbon and oxygen isotope ratios of tree ring cellulose from European larch obtained at a high-elevation site in the Swiss Alps ( $2100 \mathrm{~m}$ above sea level). Unlike tree ring width and maximum latewood density, which contain only summer temperature information at this site, we found that our stable isotope series reveal additionally to temperature a striking sensitivity to precipitation (mainly for carbon) and sunshine duration (mainly for oxygen) during July and August. A drought index reflecting the combined temperature and precipitation influence provided the most stable correlations over time for the carbon isotope series. All of these climate-isotope relationships are preserved in the isotope series obtained from younger trees at the same site, while strong intertree correlations further emphasize the high climate sensitivity. We thus present the first carbon-isotope-based summer drought reconstruction for the Swiss Alps, which provides new evidence for interannual to long-term changes in summer regional moisture variability from 1650 to 2004 in Europe, revealing extreme drought summers in the second half of the 18th century and throughout the 20th century.

Citation: Kress, A., M. Saurer, R. T. W. Siegwolf, D. C. Frank, J. Esper, and H. Bugmann (2010), A 350 year drought reconstruction from Alpine tree ring stable isotopes, Global Biogeochem. Cycles, 24, GB2011, doi:10.1029/2009GB003613.

\section{Introduction}

[2] For Europe, a dense network of suitable proxies for climate reconstruction exists with long instrumental records, detailed documentary evidence, and highly temporally resolved natural archives. Despite the variety of proxy data, most climate reconstructions are focused on temperature, even though precipitation arguably plays a key role for human sustenance and economies as well as for many terrestrial ecosystems. Despite its importance, relatively little is known about past changes in precipitation regimes [e.g., Seager et al., 2007]. Knowledge concerning the range of variability in hydroclimatic variables, such as regional precipitation, and the occurrence of both extreme events (droughts and floods) and long-term trends (multidecadal to

\footnotetext{
${ }^{1}$ Paul Scherrer Institut, Villigen PSI, Switzerland.

${ }^{2}$ Swiss Federal Institute for Forest, Snow, and Landscape Research, Birmensdorf, Switzerland.

${ }^{3}$ Department of Geography, Johannes Gutenberg University Mainz, Mainz, Germany.

${ }^{4}$ Forest Ecology, Department of Environmental Sciences, ETH Zurich, Zurich, Switzerland.
}

Copyright 2010 by the American Geophysical Union. 0886-6236/10/2009GB003613 centennial-scale pluvial or drought periods), are of particular interest [e.g., Cook et al., 2004; Esper et al., 2007b].

[3] Continuous European hydroclimatic reconstructions covering the last few centuries are sparsely distributed and concentrated in southwestern Europe and the Mediterranean region [e.g., Esper et al., 2007b; Touchan et al., 2008]. Long-term hydroclimatic records are particularly rare in central and northern Europe. Recent efforts to reconstruct precipitation and drought fluctuations for central Europe are based on documentary evidence [Brazdil et al., 2005], tree rings [Büntgen et al., 2009; Oberhuber and Kofler, 2002; Wilson et al., 2005], or multiproxy approaches [Casty et al., 2005; Pauling et al., 2006]. However, highly temporally resolved, documentary-based reconstructions may fail to capture low-frequency signals, as descriptive evidence is discontinuous and biased by the perception of the observer [Brazdil et al., 2005], while the preservation of longer-term trends in tree-ring-based climate reconstructions is potentially restricted by the need to remove the biological agerelated trend [Cook et al., 1995] and may also be limited by an age-specific climate response [Esper et al., 2008]. The diverse nature and characteristics of proxy records, their patchy spatial distribution over Europe, and high regional precipitation variability result in a challenging larger-scale comparison and interpretation of these records [Raible et al., 2006]. 
[4] The existence of rather few tree-ring-based hydroclimatic records in Europe reflects the limited capability of the common proxies to reliably capture a moisture signal. Climate reconstructions from tree ring width and maximum latewood density, for example, are based upon annual cambial activity. At extreme sites (e.g., treeline sites), tree growth is usually limited by one climatic factor (e.g., temperature), while in temperate forests, the delineation of growth responses to a single controlling factor often fails [Friedrichs et al., 2008]. Reliable hydroclimatic reconstructions from tree ring evidence are thus restricted to very few moisture-sensitive sites [e.g., Wilson et al., 2005; Büntgen et al., 2009].

[5] Stable carbon $\left(\delta^{13} \mathrm{C}\right)$ and oxygen $\left(\delta^{18} \mathrm{O}\right)$ isotopes in tree rings differ from the classical dendrochronological variables as they reflect physical conditions and tree responses rather than measuring the net tree growth. While $\delta^{13} \mathrm{C}$ values depend on variables affecting the photosynthetic uptake of $\mathrm{CO}_{2}$ and are predominantly modulated by stomatal conductance and the rate of carboxylation during photosynthesis [Farquhar et al., 1989], $\delta^{18} \mathrm{O}$ values are constrained by the isotopic ratio of the source water [Roden et al., 2000] and locally integrate stomatal conductance, which is coupled with transpiration [Barbour et al., 2004; Yakir et al., 1990]. As these external and internal factors controlling isotopic signatures are fortunately closely correlated with meteorological variables, such as, e.g., relative humidity [Loader et al., 2008], stable isotopes may provide complementary climatic information in areas where the climate-ringwidth relationship is weak, or they may help to confirm long-term climatic trends inferred from tree ring width or maximum latewood density series. Numerous studies have demonstrated the potential of stable isotopes for the reconstruction of various climate variables, such as temperature [e.g., Gagen et al., 2007; Hilasvuori et al., 2009], precipitation [e.g., Treydte et al., 2006], and cloudiness [Young et al., 2010]. Although climate reconstructions have been derived from well-replicated [e.g., Gagen et al., 2007] and millennial-length [e.g., Treydte et al., 2006] isotopic data, the attribution of a single climate variable to stable isotope series is complex and seems to be highly site dependent. Mostly a mixed climatic signal, typically temperature in combination with precipitation, appears to be reflected in isotope ratios [e.g., McCarroll and Pawellek, 2001; Treydte et al., 2001]. Because several factors control isotope variability under most conditions, reconstructions of a single climate variable are prone to oversimplification [McCarroll and Loader, 2004], and palaeoclimate reconstructions of single climate variables from stable isotopes may therefore be of varying reliability [Reynolds-Henne et al., 2007]. Nevertheless, recent isotope network studies have demonstrated an astonishingly strong intersite coherence for $\delta^{18} \mathrm{O}$ [Saurer et al., 2008; Treydte et al., 2007], which may be related to atmospheric circulation patterns as the primary driving factor. Disentangling the role of the main controls of isotope fractionation and their associated meteorological variables is highly desirable in order to obtain reliable climate reconstructions from stable isotopes.

[6] In this study, we assess the climate-isotope relationship for a 350 year carbon and oxygen isotope series ob- tained from tree ring cellulose of European larch (Larix decidua Mill.) grown at treeline sites in the Lötschental, Swiss Alps. Using these new isotope chronologies, we carry out a detailed sensitivity study of carbon and oxygen isotopes and regional climate. On the basis of these analyses, we (1) provide new insights regarding the climate signal contained in carbon and oxygen isotope series and (2) present the first carbon-isotope-based drought reconstruction for the European Alps. This reconstruction provides new evidence for interannual to long-term changes in regional summer moisture variability from A.D. 1650 to 2004 .

\section{Material and Methods}

\subsection{Study Site and Sampling Strategy}

[7] The central alpine valley Lötschental is the largest side valley on the northern side of the Rhône river in the Valais, Switzerland (Figure 1 and Table 1). Its climate is characterized by the influence of the oceanic temperate moist regime of the northern Alps and the dry subcontinental climate of the inner alpine Rhône valley, which is one of the driest regions in Switzerland. Therefore, the climate can vary with high interannual differences in total precipitation, which may lead to sporadic strong droughts during the vegetation period [Treydte et al., 2001]. The vegetation of the Lötschental is dominated by the subalpine belt of spruce-larch forests, which is gradually mixed with larch-Swiss Stone pine forests toward the upper timberline, which is presently located between 2100 and $2200 \mathrm{~m}$ above sea level (asl). The differences in treeline elevation in the current landscape are related to the varying intensity of alp pasturing rather than climatic influences [Paulsen and Körner, 2001]. The old-aged living larch and spruce trees, together with wood preserved in historical buildings, has made the Lötschental an area of prime dendrochronological interest. Temperature reconstructions spanning the past millennium [Büntgen et al., 2005, 2006], dendroecological network analyses [Frank and Esper, 2005], isotopic site comparisons [Treydte et al., 2001], reconstructions of larch budmoth activity [Esper et al., 2007a; Kress et al., 2009a], and more recently the assessment of intra-annual tree growth along elevational transects [Moser et al., 2010], and intra-annual isotopic discrimination among the atmosphere-soil-plant systems (S. Y. Boda et al., Intra-seasonal pathway of oxygen isotopes from soil to wood in the Lötschental (Swiss Alps), submitted to Plant Cell Environment, 2010) have been performed.

[8] In this study, samples of European larch (Larix decidua Mill.) were collected at two treeline locations situated within the larch-Swiss Stone pine forests: at the SSEfacing slope (2100 $\mathrm{m}$ asl) above the village Blatten $(1540 \mathrm{~m}$ asl) and the NNW-facing slope (2200 m asl) above the village Kippel (1376 m asl). The steep slopes are characterized by rather shallow soils. While at the SSE-facing, sunny slope, podzolic cambisols are dominant, the NNWfacing, shady slope provides more humid soil conditions, i.e., ferric podzols [Treydte et al., 2001]. At each site, trees were cored in two different age classes $(450-550$ years and $150-250$ years); thereby care was taken to select trees under similar growth conditions (diameter at breast height, com- 


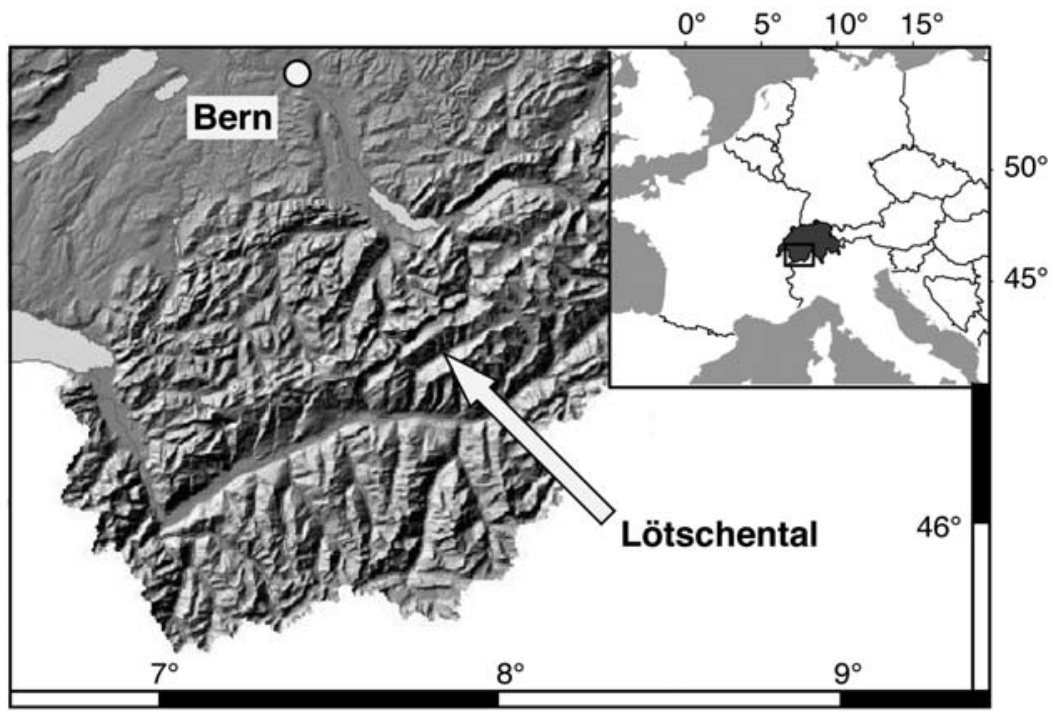

Figure 1. Larix decidua Mill. sampling site Lötschental situated in the Swiss Alps, Valais, Switzerland. Reproduced by permission of the Swiss Federal Office of Topography (JA082268).

petition, and microsite conditions). Each tree was cored twice at breast height $(1.30 \mathrm{~m})$ using a $5 \mathrm{~mm}$ increment borer.

\subsection{Sample Analysis}

[9] Tree ring widths were measured with a resolution of $0.01 \mathrm{~mm}$ using a semiautomated RinnTech system (Heidelberg, Germany) coupled to the TSAP tree ring program, cross-dated [Stokes and Smiley, 1968] against a local master chronology [Büntgen et al., 2005] and verified by using the program COFECHA [Holmes, 1983]. For isotope analysis, five trees (two cores each) were chosen within the age class of 450-550 years, three of them from the SSEfacing slope and two from the NNW-facing slope, respectively, and eight trees within the younger age class (four from each slope), a number shown to be satisfactory to establish a representative isotope site record [e.g., McCarroll and Loader, 2004; Treydte et al., 2007].

[10] Tree rings were split year-by-year for A.D. 1650 2004 (age class 450-550 years) and A.D. 1900-2006 (age class 150-250 years). Isotope analysis of 50 subsamples of earlywood and latewood showed a very strong and coherent correlation between the two components, thus justifying whole-ring analysis [Kress et al., 2009b]. This was fortunate, as the very narrow rings would make ring separation technically difficult and often leave insufficient material for isotopic measurements. As pooling rings of the same year prior to analysis was shown to retain climatic signals with little if any degradation and results in a great decrease in workload and necessary measurements [Treydte et al., 2007], we adopted two pooling approaches. The old trees were analyzed on a single-tree basis for A.D. 1901-2004 and using the so-called "10 year split pool approach" for A. D. 1650-1900, where years were pooled prior to analysis with single-tree measurements every 10th year. The breakup of the pool in regular intervals allows testing of the signal strength within the different trees. The younger trees were annually pooled prior to analysis for the entire period analyzed (A.D. 1900-2006).

[11] Alpha-cellulose was extracted following standard procedures [Boettger et al., 2007] adapted for larch samples, homogenized by sonification, and freeze-dried for $24 \mathrm{~h}$ [Kress et al., 2009a]. Carbon isotopic ratios were determined after combustion of samples to $\mathrm{CO}_{2}$ at $1025^{\circ} \mathrm{C}$ in an elemental analyzer (EA-1110; Carlo Erba Thermoquest, Milan, Italy) coupled to an isotope ratio mass spectrometer (Delta $\mathrm{S}$ or Delta Plus XL; Thermo Finnigan Mat, Bremen, Germany) with a reproducibility of $0.1 \%$. Oxygen isotopic ratios were analyzed with a reproducibility of $0.3 \%$ after pyrolysis to $\mathrm{CO}$ at $1080^{\circ} \mathrm{C}$ using a continuous flow method and a Delta Plus XP connected via a variable open-split interface Conflo III (both Thermo Finnigan Mat, Bremen, Germany) [Saurer and Siegwolf, 2004]. All isotope values are expressed in the delta notation relative to an international standard (VPDB for $\delta^{13} \mathrm{C}$ and VSMOW for $\delta^{18} \mathrm{O}$ ). All carbon records were corrected for the atmospheric decline in $\delta^{13} \mathrm{C}$ due to fossil fuel burning

Table 1. Site Description of the Lötschental

\begin{tabular}{ccccccc}
\hline Site & Latitude $\left({ }^{\circ} \mathrm{N}\right)$ & Longitude $\left({ }^{\circ} \mathrm{E}\right)$ & Aspect & Slope & Altitude (m asl) & Soils ${ }^{\mathrm{a}}$ \\
\hline Lötschental south facing slope & $46^{\circ} 26^{\prime}$ & $7^{\circ} 48^{\prime}$ & SSE & $35^{\circ}$ & 2100 & ferric podzols \\
Lötschental north facing slope & $46^{\circ} 23^{\prime}$ & $7^{\circ} 47^{\prime}$ & NNW & $40^{\circ}$ & 2200 & podzolic cambisols \\
\hline
\end{tabular}

\footnotetext{
${ }^{a}$ According to Food and Agriculture Organization of the United Nations soil classification.
} 
since the beginning of the industrialization [Leuenberger, 2007].

[12] The signal strength of the carbon and oxygen isotope chronologies was assessed for the chronologies obtained within the $450-550$ year age class by using the average interseries correlation (RBAR) and the expressed population signal (EPS) statistics [Wigley et al., 1984]. While RBAR is a measure of common variance between single series, independent of the number of series, EPS measures the degree to which the chronology approaches the theoretical population chronology from which it was drawn. On the basis of the example from Wigley et al. [1984], the threshold for sufficient signal strength is often set to EPS $>0.85$. Additionally, we calculated the coefficient of variation $(\mathrm{CV})$, a normalized measure of dispersion, to address the range of values within the chronologies.

\subsection{Climate Data}

[13] Climate calibration was performed using the HISTALP database, an alpine-wide meteorological data set [Auer et al., 2007]. We compared all four-isotope series with the existing temperature (19), precipitation (32), and sunshine duration (11) series obtained from the Swiss part of the HISTALP database. For correlation analysis a mean of all climate series was taken for each climate variable, as various tests showed that correlations with the mean were equally strong or stronger than with any of the single climate series [see also Blasing et al., 1981]. Correlations were calculated on a monthly basis from previous year March to current year December as well as seasonal averages for A.D. 1901-2004, using bootstrapped correlation analysis for significance testing ( $\mathrm{p}<0.001)$ [Guiot, 1991]. By calculating running correlations between the monthly records and both isotope series over 40 year time windows, we tested the temporal stability of the climate-isotope relationship. In addition, spectral analyses were performed using the multitaper method (MTM, 2 year resolution, 3 tapers) of the Spectra software [Ghil et al., 2002].

[14] To further investigate spatial climate correlations, we used temperature and precipitation data of an updated version of the $0.5^{\circ} \times 0.5^{\circ}$ monthly gridded meteorological data set CRU TS 3 [Mitchell and Jones, 2005] as well as various monthly resolved self-calibrating Palmer Drought Severity Index (scPDSI) data sets available for the European Alps (10 min latitudinal-longitudinal resolution) [van der Schrier et al., 2007], central Europe $\left(0.5^{\circ} \times 0.5^{\circ}\right.$ grid) [van der Schrier et al., 2006], and the globe $\left(2.5^{\circ} \times 2.5^{\circ}\right.$ grid $)$ [Dai et al., 2004], accessed via the KNMI climate explorer (http://climexp.knmi.nl).

[15] In addition, we assessed the relationships between different climate variables and the climate-isotope relationship prior to the 20th century by using the monthly resolved temperature and precipitation reconstruction of Casty et al. [2005] from the grid cell $46.25^{\circ} \mathrm{N} 7.75^{\circ} \mathrm{E}$ covering the Lötschental (A.D. 1660-2000), as well as a drought index derived from these reconstructions (see section 2.4).

\subsection{Drought Index}

[16] For A.D. 1901-2004 a simple drought index (DRI) [Bigler et al., 2006] was calculated on the basis of the temperature and precipitation amount series of the Swiss part of the HISTALP data set [Auer et al., 2007]:

$$
\mathrm{DRI}=P-\mathrm{PET}
$$

with $P$ equal to the monthly precipitation amount and PET equal to the monthly sum of estimated potential evapotranspiration as a function of monthly mean temperatures and geographical latitude, following the formulation of Thornthwaite [1948]. DRI values were calculated on a monthly basis. We used the simple DRI rather than a more mechanistic drought index for several reasons: (1) Bigler et al. [2006] showed no significant improvement compared to the more complex drought index by Bugmann and Cramer [1998]; (2) no assumptions about detailed parameters such as soil water holding capacity are necessary for calculating DRI; and (3) a drought index that captures wet and dry extremes rather than just indicating dry extremes was more suitable to fully characterize moisture variability. DRI values are easily interpretable as regional water availabilities; values below zero indicate moisture deficits, whereas values above zero indicate water excess.

[17] DRI signal analyses were conducted for high-pass and low-pass filtered data using cubic smoothing splines with a $50 \%$ frequency response cutoff at 10 years [Cook and Peters, 1981]. On the basis of monthly correlation results, a July-August DRI reconstruction was built from $\delta^{13} \mathrm{C}$ using simple linear regression. To assess the predictive skill, explained variance $\left(R^{2}\right)$ of the regression models, reduction of error statistic (RE) [Fritts, 1976], coefficient of efficiency (CE) [Cook et al., 1994], and the Durbin-Watson statistic (DW) [Durbin and Watson, 1951] were systematically compared for independent calibration and verification periods. While RE and CE are measures of shared variance between target and proxy series and generally lower than $R^{2}$ [Cook et al., 1994; Fritts, 1976], the DW tests for first-order autocorrelations in the model residuals. A DW value of 2 indicates no first-order autocorrelation in the residuals, whereas a value of DW $>2(\mathrm{DW}<2)$ suggests negative (positive) autocorrelation [Durbin and Watson, 1951]. Reconstruction errors were estimated by the root-meansquared error (RMSE) of the prediction [Wilks, 2006] divided by the 51 year running RBAR (maximum value within each 51 year window) of the carbon isotope series.

[18] Last, comparisons were performed with three different reconstructions of spring and summer precipitation from central Europe [Oberhuber and Kofler, 2002; Wilson et al., 2005] (R. Wimmer in the work of Büntgen et al. [2009]) and one recent summer drought reconstruction from Slovakia [Büntgen et al., 2009]. All these reconstructions are annually resolved and based on tree ring widths.

\section{Results}

\subsection{Signal Strength in Carbon and Oxygen Isotope} Series

[19] Annually resolved $\delta^{13} \mathrm{C}$ (Figure 2) and $\delta^{18} \mathrm{O}$ (Figure 3) chronologies obtained from older (450-550 years) and younger (150-250 years) trees are highly synchronous at the individual tree level for A.D. 1900-2004 

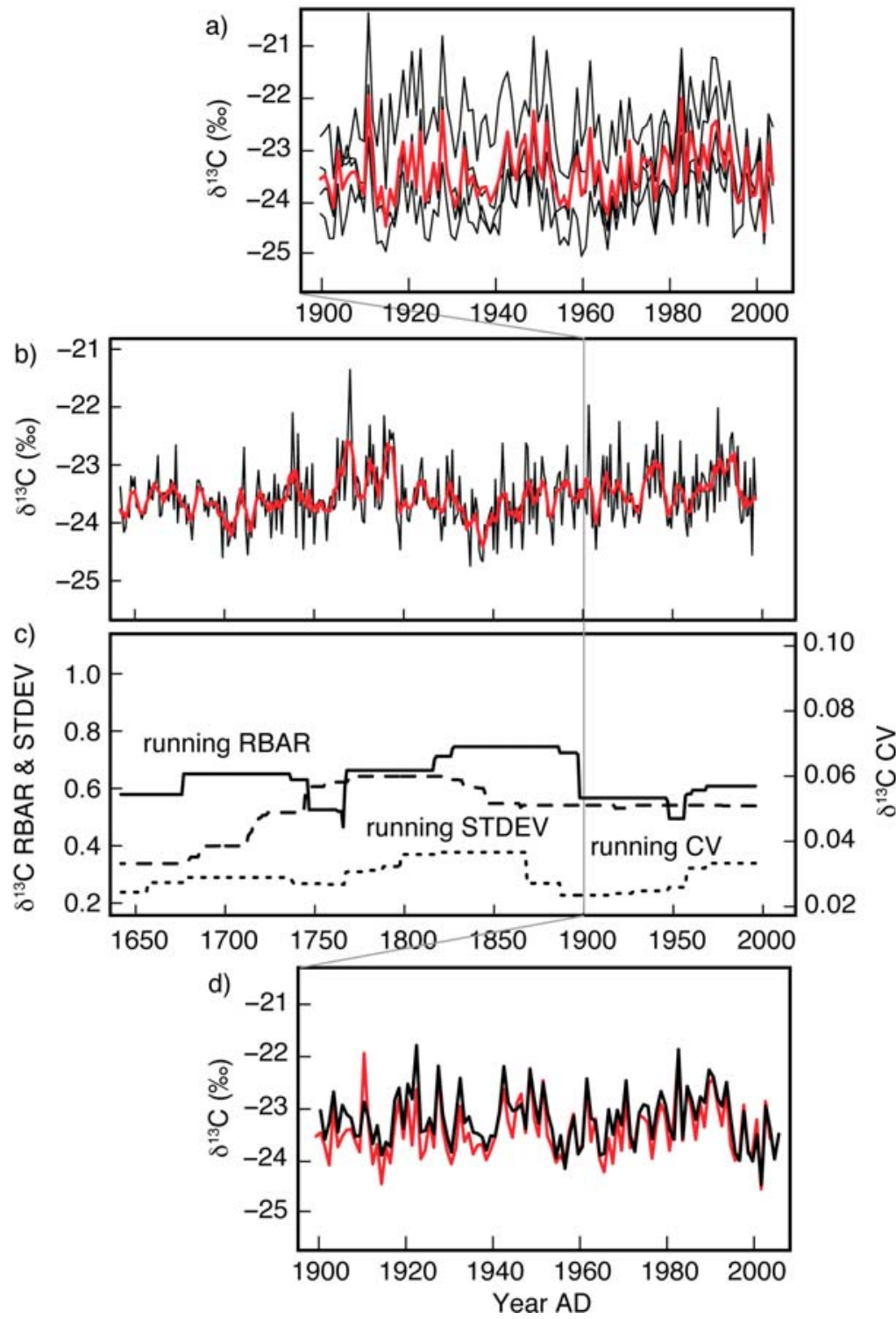

Figure 2. Carbon chronology characteristics: (a) Single-tree series (black lines) and their average (red line) for A.D. 1900-2004; (b) annually resolved mean of five trees (black) and a 5 year centered running mean (red) for A.D. 1650-2004; (c) 51 year moving windows of interseries correlations (RBAR) and coefficient of variation (CV) of the split pool values (every 10th year) as well as the standard deviation of the chronology mean (STDEV); (d) comparison with younger larch trees (150-250 years; black line) for the 20th century.

(Figures $2 \mathrm{a}$ and $3 \mathrm{a}$ ). The lack of climate signal age effects [Esper et al., 2008] as well as the robustness of the mean based on five trees are emphasized in the comparison with the isotope series obtained from younger trees (Figures $2 \mathrm{~d}$ and $3 \mathrm{~d}$ ). The $\delta^{13} \mathrm{C}$ and $\delta^{18} \mathrm{O}$ series from both age classes yield a virtually identical mean. To assess this signal strength back in time, 51 year centered running RBAR and EPS (the latter is not shown in Figures 2 and 3) statistics were computed on the basis of the individual isotope values available every 10 th year. Both isotope series revealed a fairly high and stable $\operatorname{RBAR}\left(\delta^{13} \mathrm{C}: \mathrm{RBAR}_{\text {mean }}=0.64\right.$; $\left.\delta^{18} \mathrm{O}: \mathrm{RBAR}_{\text {mean }}=0.77\right)$ and exceed the EPS threshold of
0.85 throughout the entire period $\left(\delta^{13} \mathrm{C}: \mathrm{EPS}_{\text {mean }}=0.89\right.$; $\delta^{18} \mathrm{O}$ : $\left.\mathrm{EPS}_{\text {mean }}=0.94\right)$, pointing to a very strong common signal within the population and a robust mean chronology. For both isotope series the coefficient of variation (CV) showed a remarkably low dispersion between the singletree isotope values, confirming not only a high synchronicity in the curve progression but also a narrow range of values in the isotope series of different trees. In addition, the 51 year running standard deviation (STDEV) is illustrated in Figures 2 and 3 to investigate potential changes in variance in the chronologies [Frank et al., 2007b]. While the STDEV of the oxygen series remained stable throughout the 

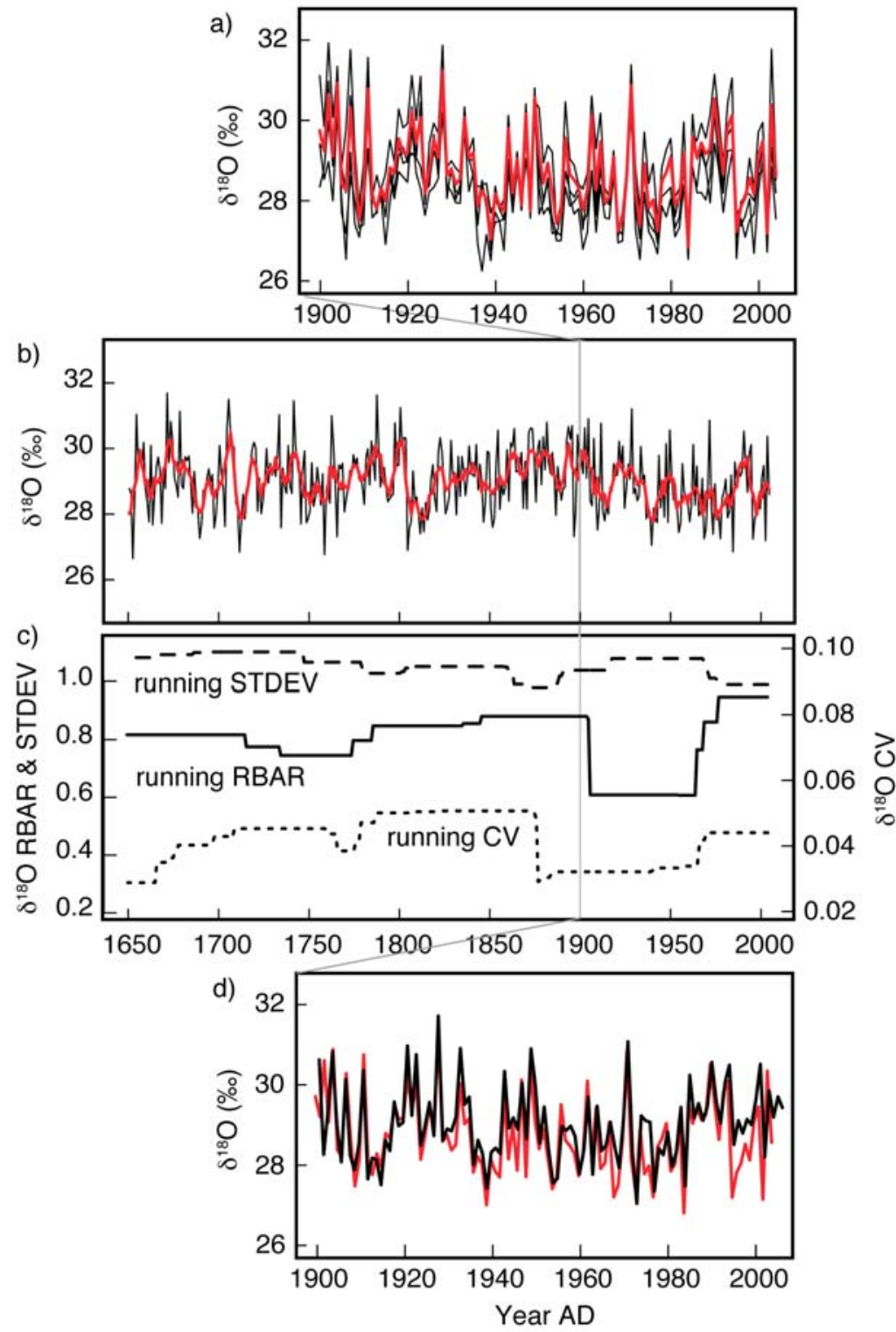

Figure 3. Oxygen chronology characteristics (Same as Figure 2 but for oxygen instead of carbon).

investigated period, the variance of the carbon series decreased slightly back in time. The consistently high RBAR, constant sample replication, and the small differences in the signal between the young and old-age trees (Figure 2) all minimize the likelihood for variance artifacts, but we are aware that changes in the variance of climatic time series must be interpreted with caution [Frank et al., 2007b]. The stability of the RBAR, EPS, and CV statistics are particularly striking when considering that all calculations are limited to very few values (tree-wise analysis was only conducted every 10th year for A.D. 1650-1899 and simulated for A.D. 1900-2004). Overall, the signal strength assessment demonstrates a very high common signal, which is indicative of climatic forcing.

\subsection{Climate Signals}

[20] For A.D. 1901-2004, bootstrapped correlation coefficients were calculated on a monthly basis for all $\delta^{13} \mathrm{C}$ and $\delta^{18} \mathrm{O}$ series and temperature, precipitation amount, sunshine duration, as well as the DRI (Figures 4 and 5). Significant correlations $(p<0.001)$, highlighted by colored bars, are restricted to a narrow window within the tree line vegetation period, which is from mid-May (stem growth starts midJune) to mid-September [Moser et al., 2010], with highly significant positive correlations for temperature and sunshine duration and strong negative correlations with precipitation amount and DRI. All signs of the correlation coefficients agree with theoretical expectations based on isotope fractionation [McCarroll and Loader, 2004]. No 
Carbon correlations with climate variables
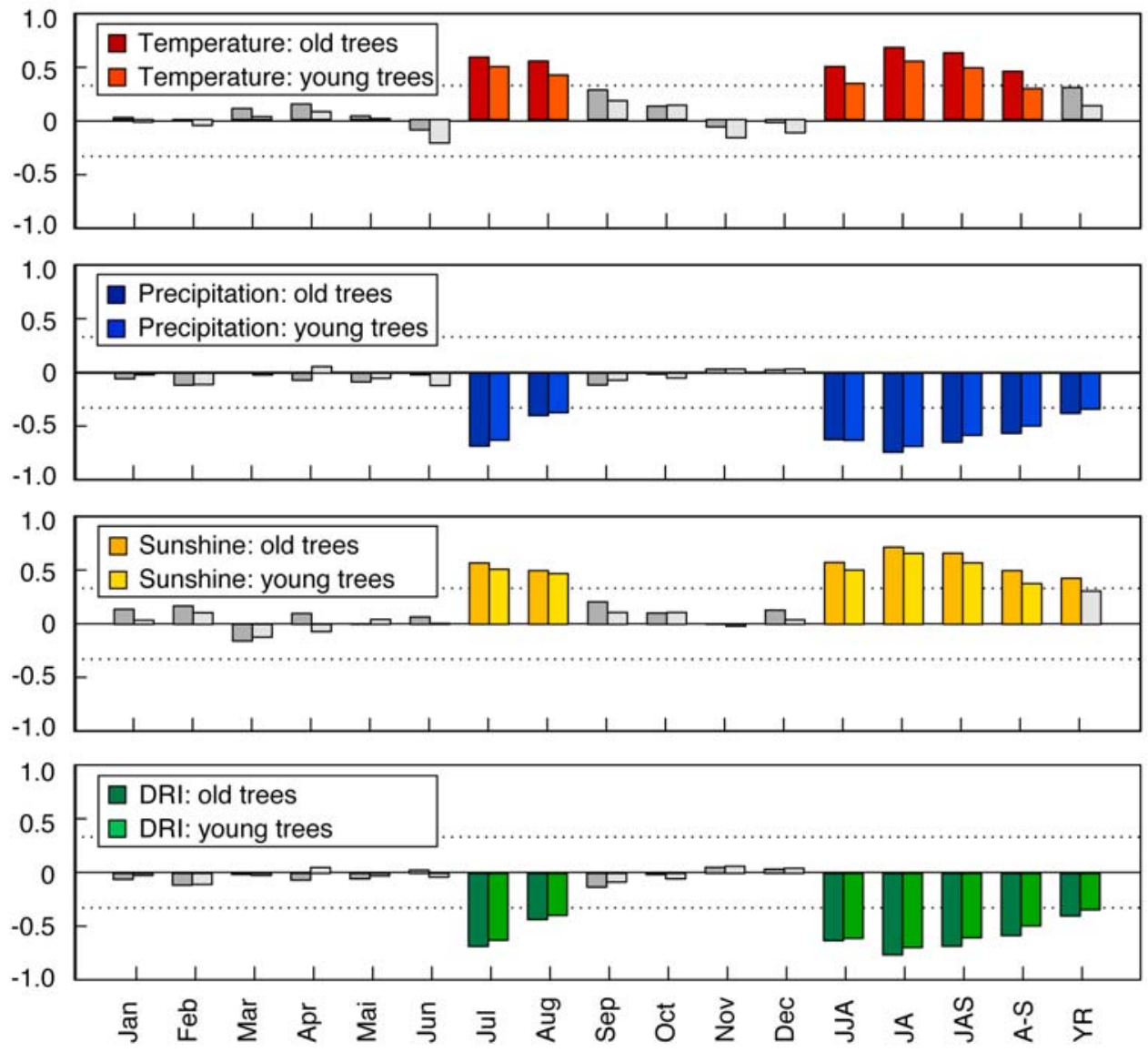

Figure 4. Colored bars illustrate significant bootstrapped correlation coefficients between $\delta^{13} \mathrm{C}$ and temperature (red), precipitation amount (blue), sunshine duration (orange) and the calculated drought index (DRI, green) for A.D. 1901-2004. Dotted lines represent 99.9\% confidence limits; gray bars represent insignificant correlations. All climate data were obtained from the Swiss part of the HISTALP data set, and all correlations were calculated for the old chronology trees (450-550 years; dark bars) and younger trees (150-250 years; light bars) from the same site.

significant correlations were found with any month of the previous year (not shown). Compared to climate response windows of tree ring width and latewood density, this midlate summer seasonal window appears particularly narrow and well defined. Highest correlation values were identified for both isotopes and all four climate variables when considering a July-August mean. Carbon isotopes correlate equally strong with all climate variables $(|r| \sim 0.7)$. However, oxygen isotopes show a much stronger relationship with sunshine duration $(r \sim 0.7)$ than with temperature, precipitation amount, and DRI $(|r| \sim 0.5)$. The strongest relationship was obtained between carbon and DRI $(r=$ $-0.76)$. As expected on the basis of the similarities in mean chronologies, all climate-isotope relationships are equally strong for the younger and older trees (Figures 4 and 5). No distinct shifts in any of the climate-isotope relationships were found when the temporal stability of the climateisotope relationship was tested (data not shown and Kress et al. [2009a]).
[21] For central Europe, strong spatial field correlations $(p<0.001)$ were found for both isotopes and both investigated climate variables (temperature and precipitation) with a particular emphasis on the Alpine arc (Figure 6). While positive July-August temperature correlations (up to $r \sim 0.7)$ emanated to southwestern Europe, the negative correlations with July-August precipitation amounts (up to $r \sim-0.7)$ were restricted to central Europe. The climateisotope relationships were somewhat more pronounced for carbon than for oxygen isotopes. Nevertheless, the spatial patterns were very similar for the two isotope series and the climate variables, suggesting a distinct regional climate signal in both isotope series.

\subsection{Identification of the Dominating Climate Signal in Carbon Isotopes}

[22] To assess the dominant climate signal in a long-term context, the carbon isotope series (A.D. 1650-2004) was compared to a July-August temperature and precipitation 
Oxygen correlations with climate variables
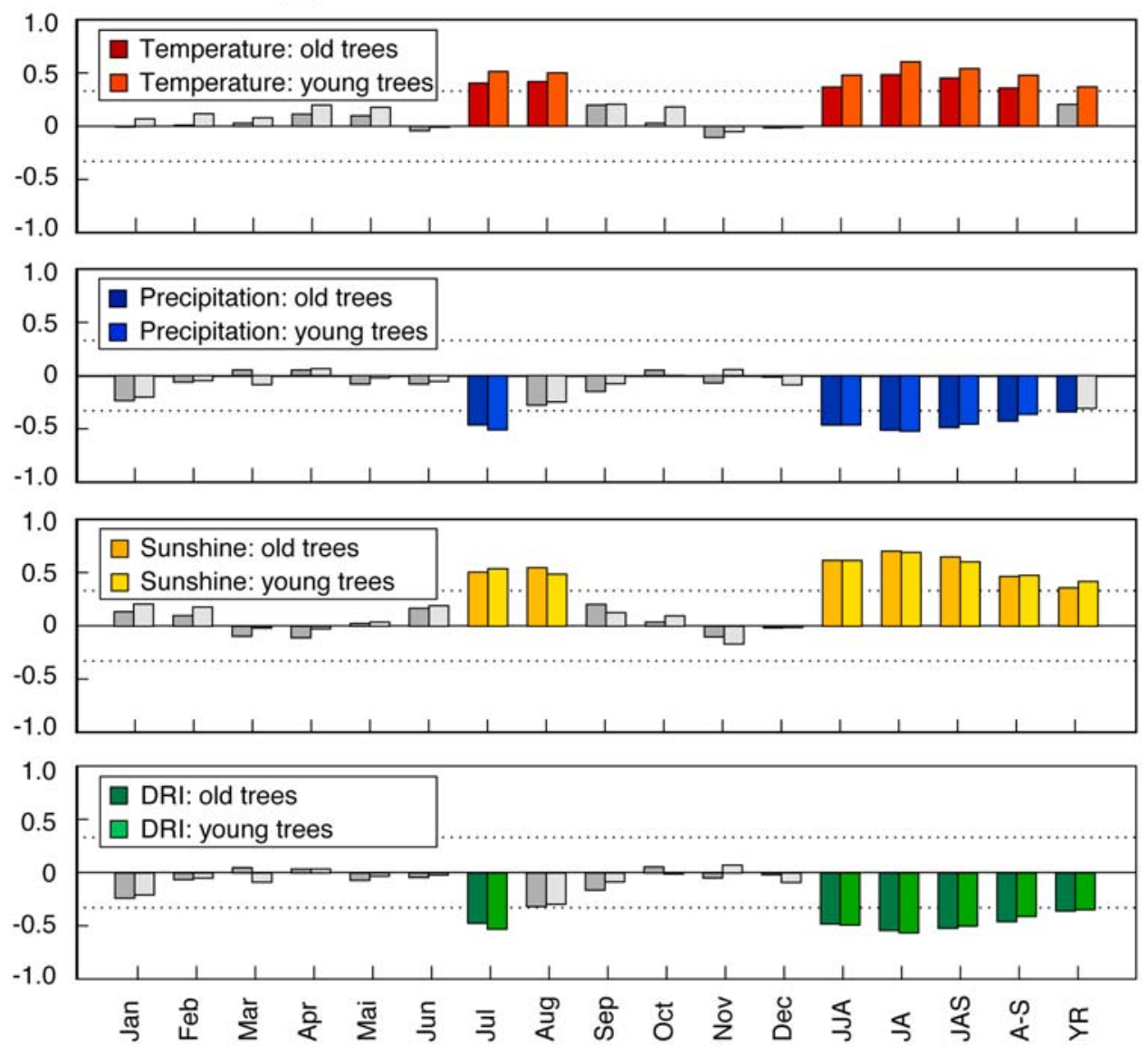

Figure 5. Correlation analysis of $\delta^{18} \mathrm{O}$ and climate variables (Same as Figure 4 but for oxygen instead of carbon).

reconstruction from the corresponding grid cell of the Lötschental (A.D. 1659-2000) [Casty et al., 2005] as well as to the July-August DRI calculated from these reconstructions (Figure 7a). Over the 342 year period of overlap, the carbon isotope series showed high agreement with the temperature reconstruction and was anticorrelated with the precipitation record. Both relationships were stronger in the more recent period, where the reconstruction of Casty et al. [2005] consists of a dense network of high-quality instrumental data and over which the carbon isotope data were already screened. The calculated DRI series was rather similar to the precipitation record but showed slightly stronger correlations with $\delta^{13} \mathrm{C}$. To assess the temporal stability of the relationships, we compared 31 year running correlations of $\delta^{13} \mathrm{C}$ with the three climate variables (Figure $7 \mathrm{~b}$ ) as well as the relationship between $\delta^{13} \mathrm{C}$ and $\delta^{18} \mathrm{O}$. Most of the time a strong relationship between the two isotopes $(r>0.5)$ was evident. However, three periods with weaker correlations could be identified: 1690-1700, 1760-1785, and 18101840. Interestingly, these periods of weak correlations between the two isotopes matched with weak correlations between carbon series and reconstructed temperature, precipitation, and DRI. In particular, the running correlations between temperature and carbon showed a sharp decline within these periods, indicating that temperature alone may not be the dominating driving factor for the $\delta^{13} \mathrm{C}$ signatures.

[23] To consider properties in the frequency domain, instrumental temperature, precipitation, calculated DRI, and $\delta^{13} \mathrm{C}$ series were analyzed using the multitaper method [Mann and Lees, 1996] over the 1900-2004 period. While spectral power is similar in all variables at frequencies above $\sim 0.05$ cycles/year, distinct differences become apparent in the lower-frequency domain (Figure 8), where the $\delta^{13} \mathrm{C}$ spectrum meets neither the temperature nor the precipitation spectrum, but is rather located between the two. The DRI spectrum reveals a most similar balance of high- frequency to low-frequency variance as the $\delta^{13} \mathrm{C}$, and again is suggestive that the DRI, by combining temperature and precipitation effects, is the most suitable variable to explain $\delta^{13} \mathrm{C}$ measurements. When the same analysis is conducted with the temperature and precipitation reconstructions by Casty et al. [2005] and compared to the spectrum of $\delta^{13} \mathrm{C}$ for A.D. 1659-2000, the reconstructed temperatures have less low-frequency variability than the $\delta^{13} \mathrm{C}$ (data not shown; see also paragraph above). 


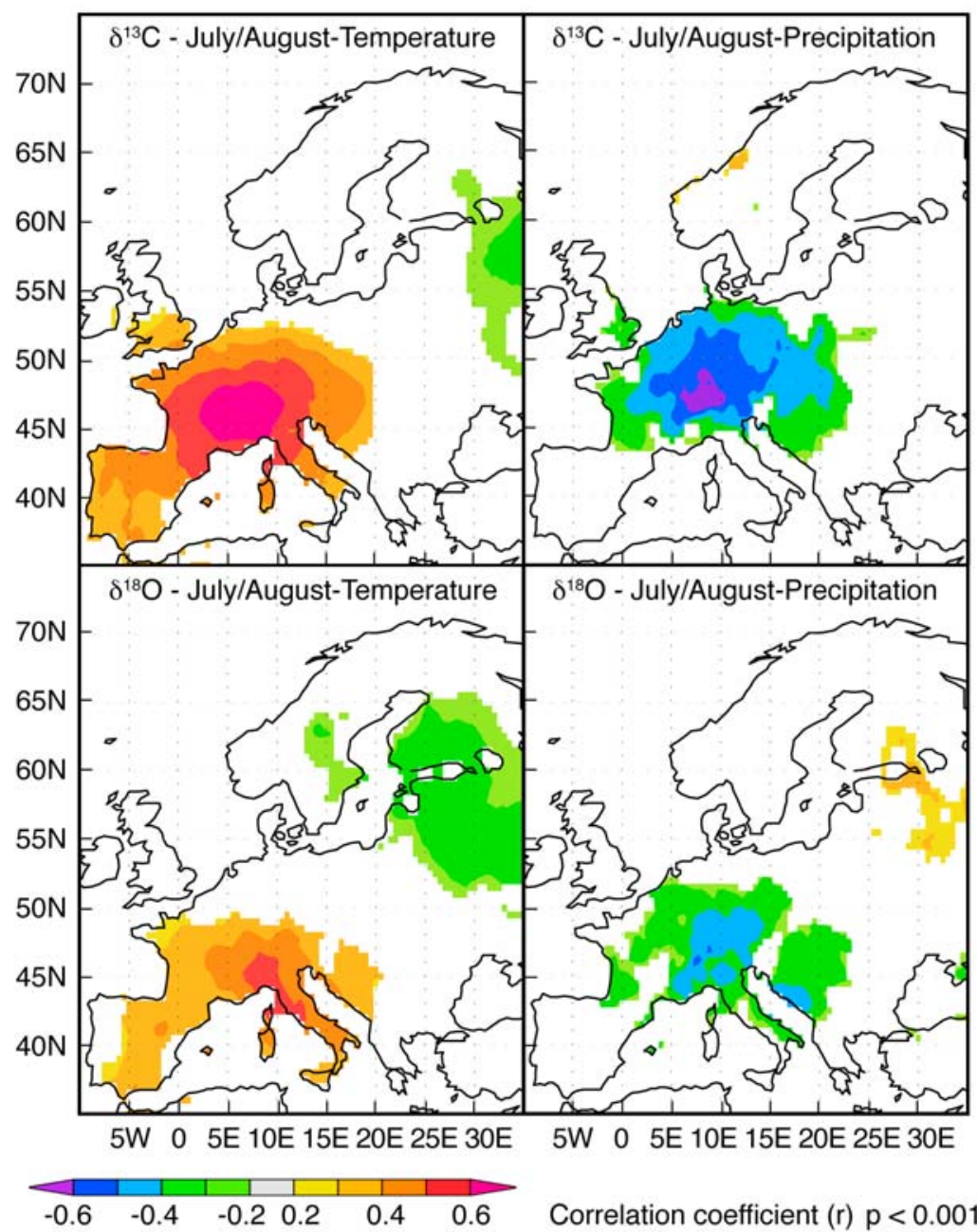

Figure 6. Significant spatial field correlations $(\mathrm{p}<0.001)$ between (top) $\delta{ }^{13} \mathrm{C}$ and (bottom) $\delta{ }^{18} \mathrm{O}$ and July-August mean temperature and precipitation amount for A.D. 1901-2004. All climate data were obtained from a $0.5^{\circ} \times 0.5^{\circ}$ monthly gridded meteorological data set (CRU TS 3).

\subsection{Drought Reconstruction}

[24] On the basis of the time and frequency domain analyses, it became increasingly clear that the July-August DRI was likely the most appropriate reconstruction target. As a final test, relationships for the raw, and high-passed and low-passed $\delta^{13} \mathrm{C}$ and DRI data (Figure 9) over the 20th century yielded nearly identical correlations of $-0.76,-0.75$, and -0.81 for the raw, high-frequency, and low-frequency domains. This suggests that the signal is appropriately balanced across all frequency domains and that $\delta^{13} \mathrm{C}$ can likely be used to reconstruct interannual to at least multidecadal signals with similar fidelity. Split period verification of the calibrated relationships (Table 2) indicated a reliable model with high predictive skill by using ordinary least squares linear regression over the full 1900-2004 period.

[25] Our July-August DRI reconstruction (LOT ${ }_{\mathrm{DRI}}$; Figure 10a) is presented with uncertainty estimates accounting for changes in the interseries relationship (see section 2). The indicated extremes are the 20 driest and wettest summers throughout the reconstruction. The three driest summers were 1778, 1911, and 1983, and the three wettest ones were 1845,1852 , and 1851 . Considering the entire record, the late 17 th and early 18 th century were rather wet followed by a dry period in the later 18th century. The entire 19th century indicated wet conditions while, except for the very beginning, the 20th century revealed rather dry conditions. On a decadal scale, four periods of severe droughts could be identified, centered on 1775, 1800, 1950, and 1990 .

\section{Discussion and Conclusions}

[26] Both the carbon and oxygen stable isotope series reveal extraordinarily strong and robust summer signals with all three investigated climatic variables (temperature, precipitation, and sunshine duration). Key characteristics of the isotope climate response include (1) highly significant correlations $(p<0.001)$ that were (2) stable through time, (3) regionally representative, and (4) evident in young and 

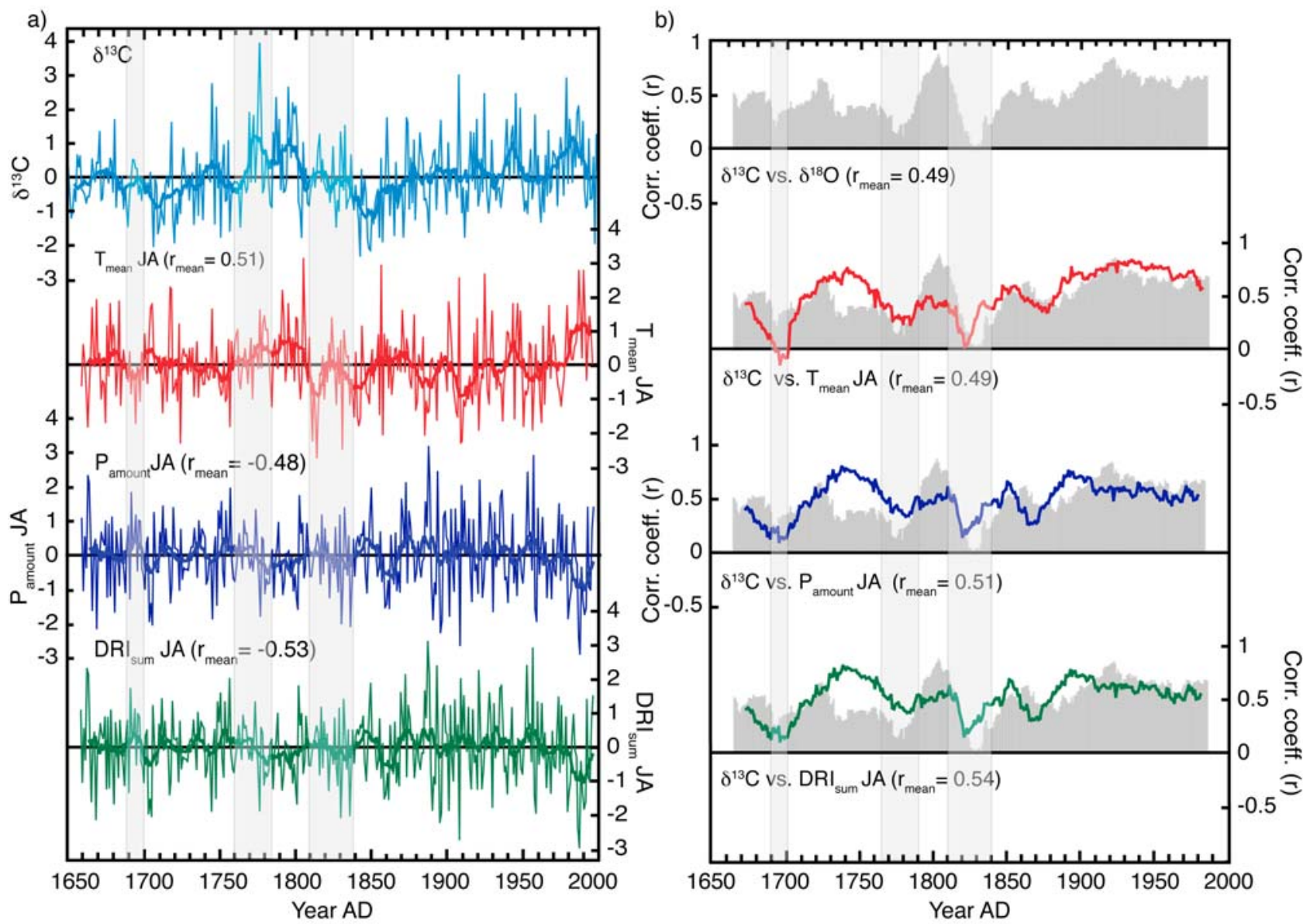

Figure 7. Comparison of $\delta^{13} \mathrm{C}$ with 350 year climate reconstructions [Casty et al., 2005]: (a) (top to bottom) $\delta^{13} \mathrm{C}$ (blue), July-August temperature $\left(\mathrm{T}_{\text {mean }} \mathrm{JA}\right.$; red), July-August precipitation $\left(\mathrm{P}_{\text {amount }} \mathrm{JA}\right.$; dark blue) and July-August drought index (DRI $\mathrm{sum}_{\text {sum }} \mathrm{J}$; green) calculated from $\mathrm{T}_{\text {mean }} \mathrm{JA}$ and $\mathrm{P}_{\text {amount }} \mathrm{JA}$; bold lines represent 11 year centered running means, shaded areas demonstrate periods of weak correlations in Figure 7b, and $\mathrm{r}$ values (Pearson's r) indicate the mean correlations between annual $\delta^{13} \mathrm{C}$ values and the corresponding climate variable. All values were standardized to the same mean $(=0)$ and standard deviation (=1) (z scores). (b) The 31 year running correlations, centered, between $\delta^{13} \mathrm{C}$ and $\delta^{18} \mathrm{O}$ series (dark gray bars) compared to the 31-year-running correlations, centered, between $\delta^{13} \mathrm{C}$ and $\mathrm{T}_{\text {mean_}} \mathrm{JA}$ (red), $\mathrm{P}_{\text {amount }} \mathrm{JA}$ (blue), and DRI $\mathrm{Dum}_{\mathrm{Ju}} \mathrm{JA}$ (green). The sign of correlation was inverted for $\mathrm{P}_{\text {amount }} \mathrm{JA}$ and $\mathrm{DRI}_{\text {sum }} \mathrm{JA}$ data. A mean-between-series correlation is given by $\mathrm{r}$. Shaded areas correspond to those in Figure $7 \mathrm{a}$ and indicate periods of weak correlations.

old trees. At the same time, our analyses failed to indicate a climatically dominating, and therefore primary controlling, factor for either of the isotopic variables. Including the results of the spectral analysis, it becomes apparent that $\delta^{13} \mathrm{C}$ is best reflected by a combination of temperature and precipitation. Although $\delta^{18} \mathrm{O}$ is likely also controlled by these two climate variables, it was not possible to increase the explained variance by a simple combination of them.

[27] Although the climate-isotope relationships shown in Figures 4 and 5 are striking, they are just statistical relationships and may not be representative of the factors directly controlling isotope fractionation in plants. According to stable isotope theory, the main controls on isotope fractionation in trees are environmental factors such as stomatal conductance, assimilation rate, photon flux (for carbon), meteoric (source) water variability, and leaf water enrichment (for oxygen) [McCarroll and Loader, 2004]. These factors are externally influenced by insolation, leaf temperature, vapor pressure deficit, and air mass properties, which, fortunately, are in turn closely correlated with meteorological variables such as air temperature, sunshine duration, and precipitation amount [Loader et al., 2008]. While at rather cool and moist high-latitude sites, carbon isotopes in tree rings tend to be dominated by variables that control the assimilation rate, mainly sunshine duration and air temperature [Gagen et al., 2007; McCarroll and Pawellek, 2001], at more xeric sites the climate signal in $\delta^{13} \mathrm{C}$ signatures seems to be mainly related to stomatal conductance, which is controlled by air humidity and water availability and is therefore linked to antecedent precipitation [Leavitt and 


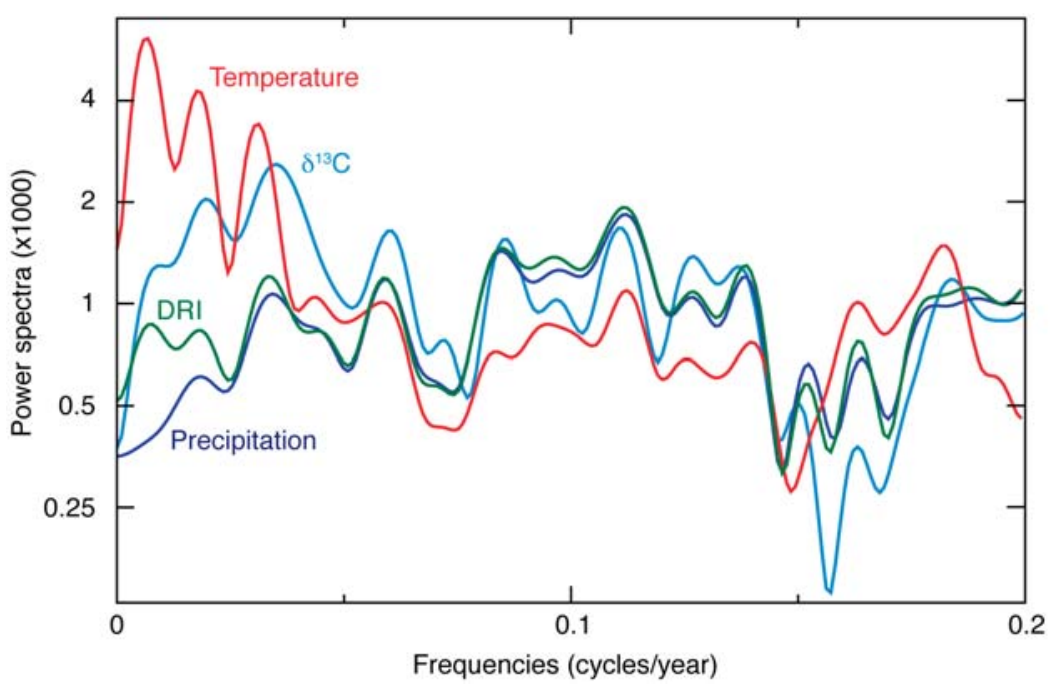

Figure 8. Multitaper method (MTM) spectra using 2 year resolution/three tapers of the $\delta^{13} \mathrm{C}$ (light blue), July-August temperature (red), July-August precipitation (dark blue), and the drought index (DRI, calculated from instrumental data, green) calculated over A.D. 1901-2004.

Long, 1988; Saurer et al., 1995]. Our altitudinal treeline site in the Lötschental, although seemingly more similar to highlatitude treeline conditions than to xeric sites, is situated in a transition zone between the oceanic moist regime of the outer parts of the Alps and the dry-subcontinental climate of the inner alpine Rhône valley. It therefore is likely that in the Lötschental, $\delta^{13} \mathrm{C}$ ratios are influenced by the interaction between assimilation rate and stomatal conductance. This is
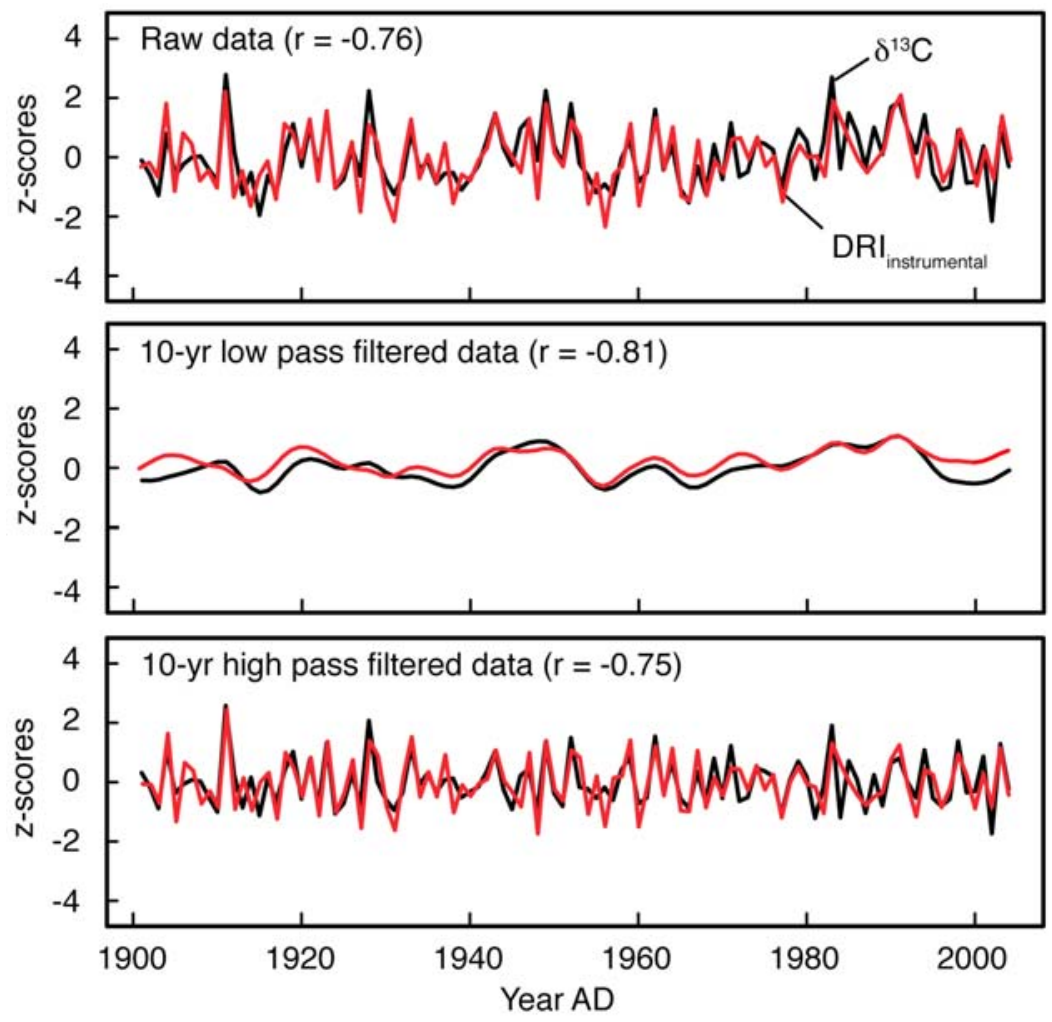

Figure 9. Carbon-isotope series (black) and July-August-DRI calculated from instrumental temperature and precipitation data (red) for (top) A.D. 1901-2004 raw and (middle and bottom) filtered data using cubic smoothing splines with 50\% frequency response cutoff at 10 years. The sign was inverted for all illustrated DRI series while r (Pearson's r) is reporting the original corresponding relationship. 
Table 2. Calibration and Verification Statistics of $\delta^{13} \mathrm{C}$ Against July-August DRI ${ }^{\mathrm{a}}$

\begin{tabular}{ccccccccc}
\hline & \multicolumn{3}{c}{ Calibration } & & \multicolumn{4}{c}{ Verification } \\
\cline { 2 - 7 } \cline { 7 - 9 } Period & $\mathrm{R}^{2}$ & RMSE & $\mathrm{DW}$ & Period & $\mathrm{R}^{2}$ & RMSE & RE & CE \\
\hline $1901-1952$ & 0.62 & 0.65 & 2.55 & $1953-2004$ & 0.54 & 0.66 & 0.60 & 0.60 \\
$1953-2004$ & 0.54 & 0.63 & 2.30 & $1901-1952$ & 0.62 & 0.65 & 0.52 & 0.52
\end{tabular}

${ }^{\mathrm{a}}$ Using simple linear regression with squared correlation coefficient $\left(\mathrm{R}^{2}\right)$, root mean squared error (RMSE), reduction of error statistic (RE), coefficient of efficiency (CE), and Durbin-Watson statistic (DW) for two independent periods. Overall period (A.D. 1901-2004): $\mathrm{R}^{2}=0.58$; $\mathrm{DW}=2.49$. DRI, drought index.

in agreement with Treydte et al. [2001], who found equally strong climate correlations of temperature, precipitation, and relative humidity with $\delta^{13} \mathrm{C}$ from Lötschental spruce (Picea abies) and suggested a crucial influence of atmospheric humidity, and therefore stomatal conductance, on carbon signatures. Therefore we suggest that a simple drought index, as shown in this study, is more likely to capture the mixed climate signal in carbon isotopes than any individually measured climate variable(s).

[28] Our study reveals higher correlations for temperature and precipitation with carbon than with oxygen values (Figures 4, 5, and 6), which is contrary to some recent studies showing equally strong climate correlations for both isotopes [Reynolds-Henne et al., 2007; Saurer et al., 2008] or stronger correlations for oxygen isotopes and summer temperature and precipitation [Loader et al., 2008; RaffalliDelerce et al., 2004]. While carbon isotopic ratios depend predominantly on leaf-internal processes, oxygen isotopic ratios in tree ring cellulose reflect mostly a dampened leaf water signal only [Barbour et al., 2004; Yakir et al., 1990], while they mainly record faithfully the isotopic composition of meteoric precipitation [Saurer et al., 1997a], which in turn depends strongly on the origin of the air masses [Dansgaard, 1964; Rozanski et al., 1993]. Locations that receive air masses of the same origin during most of the time are thus likely to show a stronger climate-isotope relationship than locations that are characterized by a more complex synoptic situation. Northern European latitudes, which are strongly influenced by North Atlantic air masses, exhibit a particularly strong temperature sensitivity of $\delta^{18} \mathrm{O}$ compared to other European sites [Treydte et al., 2007]. The Alps, however, are characterized by a strong seasonal pattern: while influenced by Northern Atlantic Oscillation (NAO) in winter, the synoptic pattern in summer is much more complex with an increased influence of regionally to locally driven systems [Casty et al., 2005]. This rather heterogeneous mixture of air mass sources during the vegetation period may influence the $\delta^{18} \mathrm{O}$ signatures in the tree rings, resulting in weaker correlations with summer temperature and precipitation amount. Correlations with summer sunshine duration, however, remain fairly strong, as sunshine duration may reflect changes in the synoptic setting and atmospheric circulation that influence the $\delta^{18} \mathrm{O}$ of precipitation. Longer sunshine hours will likely be accompanied by a decrease in precipitation and relative humidity and will therefore result in an increase of evaporative leaf water enrichment. The $\delta^{18} \mathrm{O}$ signal should thus also contain waterbalance information. In addition, sunshine duration is more closely related to the amount of shortwave radiation und thus leaf surface temperature, which also determines leaf $\mathrm{H}_{2}^{18} \mathrm{O}$ enrichment [Barbour et al., 2004].

[29] Furthermore, the inability of carbon isotopes to capture the signal of one dominating climate variable seems to be linked to the relationships observed between carbon and oxygen isotopes (Figure 7). While both isotopes are strongly correlated with each other most of the time, there are significant periods with almost no correlation, which coincide with periods of a weak summer temperature signal in carbon isotopes. In the lower-frequency domain, DRI and $\delta^{13} \mathrm{C}$ agreed well during the more recent period. Before A.D. 1850 in contrast (Figure 7), the calculated DRI showed a reduction in low-frequency variance not seen in the $\delta^{13} \mathrm{C}$. It should be considered that the DRI derived from the Casty et al. [2005] reconstruction becomes more uncertain back in time, changing from instrumental records in the modern period to fewer records overall and an increasing proportion of documentary and other, quantitatively less reliable sources. Also, methodological details may result in variance artifacts and losses [Frank et al., 2007b; Lee et al., 2008]. The majority of instrumental records drops out around A.D. 1850 , which coincides with the first and strongest period of weak correlations. In addition, the necessary homogenization procedures applied to instrumental station data are prone to error or uncertainty [Frank et al., 2007a]. Nevertheless, DRI accounts for more variance in the $\delta^{13} \mathrm{C}$ series than the temperature or precipitation reconstructions alone, and it also tends to have a more constant relationship over time. The fact that the strength of the $\delta^{18} \mathrm{O}-\delta^{13} \mathrm{C}$ and $\delta^{13} \mathrm{C}-$ DRI relationships generally rise and fall in parallel suggests linkages either to changes in the regional radiation budget (e.g., cloud cover) or to changes in the relationship between the climate variables. External factors, in particular moisture conditions, can influence both isotopic ratios [Saurer et al., 1997b]. On the leaf level, for example, stomatal conductance has a major influence on both isotopes: carbon isotopic ratios are directly linked to stomatal conductance (fractionation due to diffusion), whereas oxygen isotopic ratios are influenced by transpiration [Barbour et al., 2004; Yakir et al., 1990], which is in turn coupled to stomatal conductance and source water. Drier conditions will therefore increase the values of both isotopes. This relationship between the two isotopes is expressed as positive correlations as long as other factors, which can alternate the isotopic composition, do not vary in time [Saurer et al., 1997b]. The Alps, however, are situated within a varying influence of NAO [Casty et al., 2005]. Air masses can thus originate from different sources resulting in varying $\delta^{18} \mathrm{O}$ values in precipitation, but they may also affect the temperature-precipitation relationship and therefore $\delta^{13} \mathrm{C}$ [Reynolds-Henne et al., 2007].

[30] The DRI explains more variance in $\delta^{13} \mathrm{C}$ than temperature or precipitation alone, which is expressed in manifold ways: (1) carbon isotopes correlate more strongly with DRI than any other climate variable (Figures 4, 5, and 7), (2) this response is consistent for the high-pass, low-pass, and unfiltered data (Figure 9), (3) the spectral power is similar 

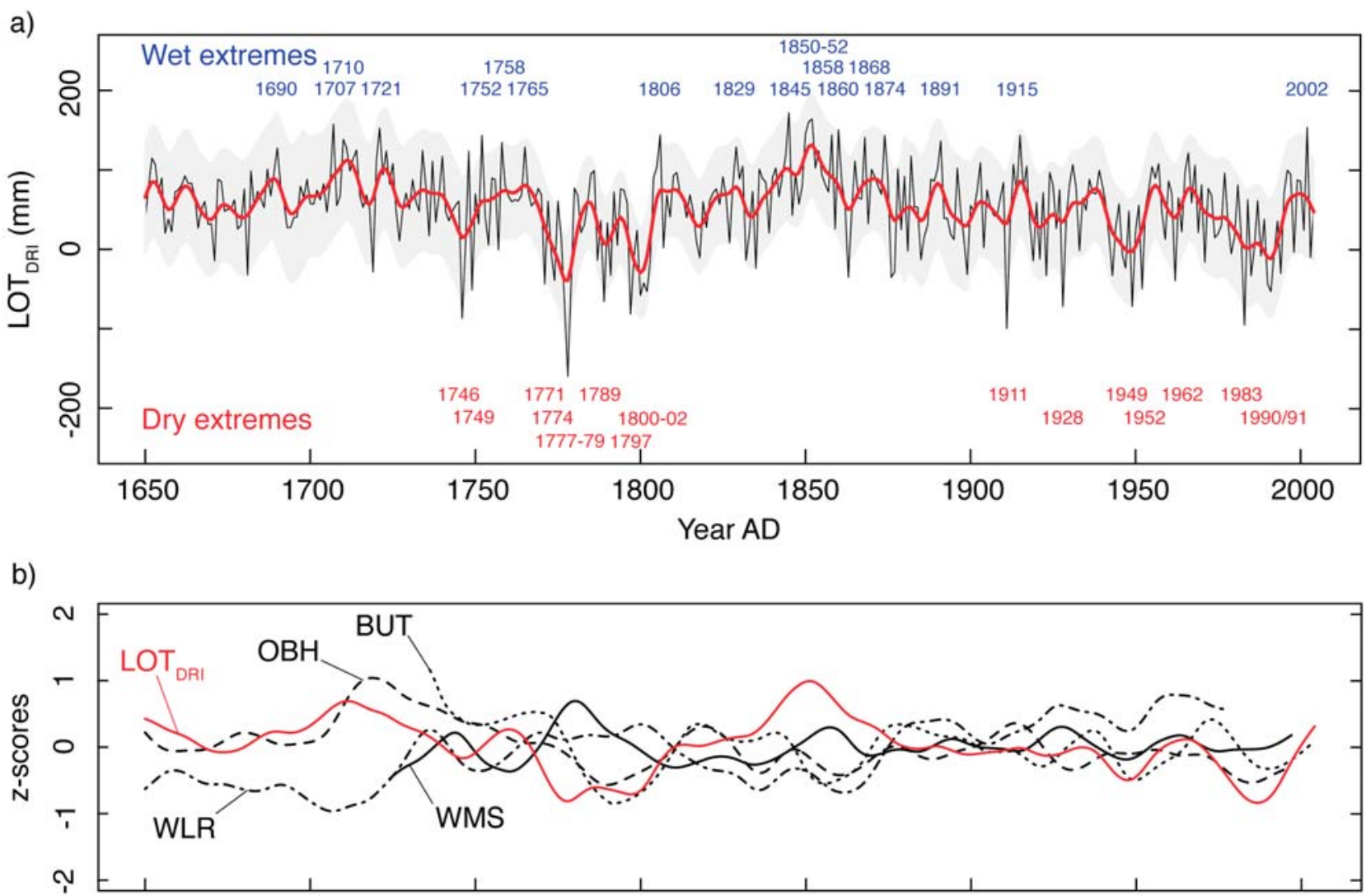

c)

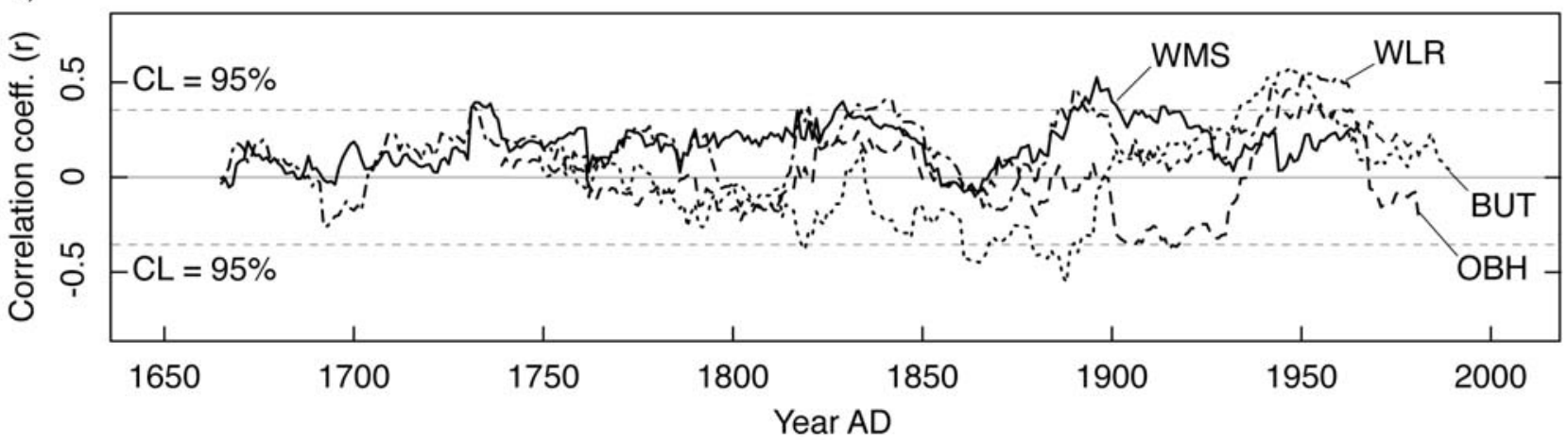

Figure 10. The $\delta^{13} \mathrm{C}$ drought reconstruction ( LOT $_{\mathrm{DRI}}$ ) and comparisons: (a) $\delta^{13} \mathrm{C}$ drought reconstruction annually resolved and 10 year low-pass filtered (bold line). Gray shadow indicates the \pm RMSE/RBAR error margin. The 20 wettest and driest years are indicated as wet/dry extreme events. (b) The 30 year low-pass filtered series of $\mathrm{LOT}_{\mathrm{DRI}}$ compared to one drought reconstruction (BUT) and three precipitation reconstructions $(\mathrm{OBH}, \mathrm{WMS}$, and WLR) from different European regions. For details of these hydroclimatic reconstructions, see Table 3 . (c) The 31 year centered running correlations between the annual $\mathrm{LOT}_{\mathrm{DRI}}$ and the other hydroclimatic records shown above (Figure 10b) within a 95\% confidence level $(\mathrm{CL})$.

across all frequency domains (Figure 8), and (4) calibration and verification statistics are strong (Table 2). These relationships and properties result in a reliable and robust DRI reconstruction $\left(\mathrm{LOT}_{\mathrm{DRI}}\right)$ with error estimates that account for changes in the interseries correlation of the individual chronology trees and are therefore of varying bandwidth. Because of the preservation of the low-frequency signal, the record not only reveals information about the occurrence of extremes, but is also able to capture decadal-scale variability. Interestingly, extremely dry summers occur only during two periods, namely during the second half of the 18 th century and during the 20th century.

[31] The LOT $_{\text {DRI }}$ reconstructed drought history was compared with other tree-ring-based reconstructions available for central Europe, by considering relationships of the raw data, after low-pass filtering, and through time using 
Table 3. Central European Hydroclimatic Series ${ }^{\mathrm{a}}$

\begin{tabular}{|c|c|c|c|c|c|c|}
\hline \multicolumn{4}{|c|}{ General Information } & \multicolumn{2}{|c|}{$\begin{array}{c}\text { Correlations } \\
\text { With LOT }_{\text {DRI }}(r)\end{array}$} & \multirow{2}{*}{$\begin{array}{c}\begin{array}{c}\text { Proportion of } \\
\text { Frequency } \\
\text { Variance }\end{array} \\
\sigma^{2}(30 \text { year } \mathrm{hp}) / \\
\sigma^{2}(30 \text { year } \mathrm{lp})\end{array}$} \\
\hline Abbreviation & Region & Signal/Season & Source & Raw & 30 year $1 p$ & \\
\hline BUT & West Carpathian & scPDSI/JJA & Büntgen et al. [2009] & 0.03 & 0.24 & 5.23 \\
\hline WMS & Vienna Basin & Precip/JJA & $\begin{array}{l}\text { R. Wimmer (in the work } \\
\text { of Büntgen et al. [2009]) }\end{array}$ & 0.20 & 0.43 & 6.75 \\
\hline WLR & Bavarian Forest & Precip/MAMJJA & Wilson et al. [2005] & -0.04 & -0.60 & 3.28 \\
\hline $\mathrm{OBH}$ & Austrian Alps & Precip/AMJ & Oberhuber and Kofler [2002] & -0.03 & -0.30 & 19.86 \\
\hline
\end{tabular}

${ }^{a}$ Compared to the new July-August drought reconstruction (LOT ${ }_{\text {DRI }}$ ) in this study. JJA, June-August; MAMJJA, March-August; AMJ, April-June; scPDSI, self-calibrating Palmer Drought Severity Index; lp, low-pass filtered data; hp, high-pass filtered data.

running correlations (Figures $10 \mathrm{~b}$ and $10 \mathrm{c}$ and Table 3 ). The only record showing a significant positive correlation with $\mathrm{LOT}_{\mathrm{DRI}}$ at all investigated frequencies is the precipitation reconstruction by R. Wimmer et al. (WMS) in the work of Büntgen et al. [2009] for the Vienna basin. If WMS and $\mathrm{LOT}_{\mathrm{DRI}}$ are compared in more detail, some similarities can be found: a rather wet late 17 th and early 18 th century, and a dry 20th century, while the other records do not show consistent correlations in the raw data. If 30 year low-pass filtered series are compared, the precipitation record of the Bavarian forest (WLR) [Wilson et al., 2005] seems to be rather anticorrelated to the $\mathrm{LOT}_{\mathrm{DRI}}$ record $(r=-0.60)$, while the precipitation record of the Austrian Alps (OBH) [Oberhuber and Kofler, 2002] and the Slovakian drought record (BUT) [Büntgen et al., 2009] express rather weak relationships to our $\mathrm{LOT}_{\mathrm{DRI}}$ reconstruction in the lowerfrequency domain. This may also indicate different preservation of low frequency in the records. While the proportion of 30 year high-frequency to low-frequency variance for LOT $_{\text {DRI }}(4.41)$ is in the range of BUT, WLR, and WMS, the OBH (19.86; compare with Table 3 ) seems to contain hardly any lower-frequency information. Nevertheless, regarding the spatial field correlations of $\delta^{13} \mathrm{C}$ and precipitation (Figure 4), which diminish toward the north and east, the regional nature of precipitation variability, and the rather large seasonal windows (in particular for OBH and WLR) compared to the very narrow and distinct response window of the $\mathrm{LOT}_{\mathrm{DRI}}$ (Figures 4 and 5), it is rather remarkable that some coherence can be found between these hydroclimatic records and the $\mathrm{LOT}_{\mathrm{DRI}}$.

[32] We chose to reconstruct DRI; however, other drought metrics such as the self-calibrating Palmer Drought Severity Index (scPDSI) are also widely used [Dai et al., 2004; van der Schrier et al., 2006, 2007]. A comparison of all scPDSI records during the 20th century for the grid cell closest to the Lötschental (Table 4) shows weak and insignificant correlations between the record of the Alps [van der Schrier et al., 2007] and the corresponding grid point from the European [van der Schrier et al., 2006] or global [Dai et al., 2004] data sets. However, the latter two data sets agree reasonably well at this location. Despite this inhomogeneous pattern of scPDSI series, the DRI shows significant, although rather weak correlations with all three of them (Table 4). This may be caused by the different approaches in calculating the scPDSI and the DRI. Although the scPDSI takes snowmelt into account, its calculation involves a rather complex water budget system, which contains empirically weighted terms of previous months' conditions and accounts therefore for a memory effect of the preceding months [van der Schrier et al., 2006]. In contrast, DRI was calculated only on the basis of the current month's temperature and precipitation data and thus does not account for any storage effects of the previous months. Despite these differences in concept and practice, some commonalities are still observed even at the continental scale. For example, considering a mean of scPDSI observations for the European continent for A.D. 1900-2004 [van der Schrier et al., 2006], the wettest summer, A.D. 1915, is well replicated in the $\mathrm{LOT}_{\mathrm{DRI}}$ reconstruction representing the second wettest summer in the 20th century. Similarly, the driest summer of the scPDSI series, A.D. 1947, is recognized as drier than average in the $\mathrm{LOT}_{\mathrm{DRI}}$. When this mean European summer scPDSI is compared to the $\mathrm{LOT}_{\mathrm{DRI}}$ on a decadal scale, all wet periods and all but one dry periods are common to both records. This coherence between a European mean of scPDSI data and the $\mathrm{LOT}_{\mathrm{DRI}}$ again emphasizes the regionally extensive signal captured by the isotopic data from the Lötschental (Figure 6).

[33] Overall, our study shows that climate reconstructions based on isotopic data using simple regression models work reasonably well as long as the relationships between meteorological variables and environmental factors controlling the isotope fractionation remain stable in time. As the Alps are situated within a varying influence of the NAO [Casty et al., 2005], we cannot expect a stable temperature-precipitation relationship back in time. Oxygen isotopes may most strongly reflect sunshine duration as meteoric variable because this is an indirect measure of evaporative leaf water enrichment. Furthermore, the analysis of the relationship between carbon and oxygen isotopes may contribute to

Table 4. A.D.1901-2004 Correlation Matrix Between Calculated DRI and Three Data Sets of scPDSI From the Grid Cell Closest to the Lötschental ${ }^{\mathrm{a}}$

\begin{tabular}{lccc}
\hline & DRI & scPDSI Europe & scPDSI Alps \\
\hline scPDSI Europe & $0.45^{* * *}$ & & \\
scPDSI Alps & $0.49^{* * *}$ & 0.10 & \\
scPDSI Globe & $0.38^{* * *}$ & $0.61 * * *$ & 0.05 \\
\hline
\end{tabular}

$\mathrm{a} * * *$ indicates $\mathrm{p}<0.001$. 
identify instabilities between meteorological variables for periods without instrumental weather data, as the different fractionation processes are not automatically linked to the same climate variables. Indices that combine temperature and moisture influences will account for instabilities between these meteoric variables, and by accounting for the different mechanisms controlling isotopic fractionation, will yield more reliable climate reconstructions. Accordingly, we presented a regional summer drought reconstruction that provides new evidence for summer temperature and water availability back to A.D. 1650 in the Alps. A small, yet crucial step toward a comprehensive understanding of longterm changes in Europe's hydroclimate.

[34] Acknowledgments. This work was funded by the EU project FP6-2004-GLOBAL-017008-2 (MILLENNIUM). J.E., D.C.F., and M.S. acknowledge support from the Swiss National Science Foundation (NCCR-Climate and 200021_121838). We thank W. Oberhuber, R. Wimmer, and R. Wilson for making their reconstructions available and in particular to U. Büntgen, who provided his very recent Slovakian drought reconstruction. Many thanks to K. Treydte, A. Verstege, D. Nievergelt, M. Tröndle, and L. Läubli for helpful discussions and technical support and to C. Bigler and $\mathrm{P}$. Weibel for sharing their rich experience in drought indices.

\section{References}

Auer, I., et al. (2007), HISTALP: Historical instrumental climatological surface time series of the Greater Alpine Region, Int. J. Climatol. 27, 17-46, doi:10.1002/joc. 1377.

Barbour, M. M., J. S. Roden, G. D. Farquhar, and J. R. Ehleringer (2004), Expressing leaf water and cellulose oxygen isotope ratios as enrichment above source water reveals evidence of a Péclet effect, Oecologia, 138 , 426-435, doi:10.1007/s00442-003-1449-3.

Bigler, C., O. U. Braker, H. Bugmann, M. Dobbertin, and A. Rigling (2006), Drought as an inciting mortality factor in Scots pine stands of the Valais, Switzerland, Ecosystems, 9, 330-343, doi:10.1007/s10021005-0126-2.

Blasing, T. J., D. N. Duvick, and D. C. West (1981), Dendroclimatic calibration and verification using regionally averaged and single station precipitation data, Tree Ring Bull, 41, 37-43.

Boettger, T., et al. (2007), Wood cellulose preparation methods and mass spectrometric analyses of $\delta^{13} \mathrm{C}, \delta^{18} \mathrm{O}$ and nonexchangeable $\delta^{2} \mathrm{H}$ values in cellulose, sugar, and starch: An interlaboratory comparison, Anal. Chem., 79, 4603-4612, doi:10.1021/ac0700023.

Brazdil, R., C. Pfister, H. Wanner, H. Von Storch, and J. Luterbacher (2005), Historical climatology in Europe: The state of the art, Clim. Change, 70, 363-430, doi:10.1007/s10584-005-5924-1.

Bugmann, H., and W. Cramer (1998), Improving the behaviour of fores gap models along drought gradients, For. Ecol. Manage., 103 247-263, doi:10.1016/S0378-1127(97)00217-X.

Büntgen, U., J. Esper, D. C. Frank, K. Nicolussi, and M. Schmidhalter (2005), A 1052-year tree-ring proxy for Alpine summer temperatures, Clim. Dyn., 25, 141-153, doi:10.1007/s00382-005-0028-1.

Büntgen, U., D. C. Frank, D. Niervergelt, and J. Esper (2006), Summer temperature variations in the European Alps, A.D. 755-2004, J. Clim., 19, 5606-5623, doi:10.1175/JCLI3917.1.

Büntgen, U., R. Brázdil, D. Frank, and J. Esper (2009), Three centuries of Slovakian drought dynamics, Clim. Dyn., doi:10.1007/s00382-0090563-2.

Casty, C., H. Wanner, J. Luterbacher, J. Esper, and R. Böhm (2005), Temperature and precipitation variability in the European Alps since 1500, Int. J. Climatol., 25, 1855-1880, doi:10.1002/joc.1216.

Cook, E. R., and K. Peters (1981), The smoothing spline: A new approach to standardizing forest interior tree-ring width series for dendroclimatic studies, Tree Ring Bull, 41, 45-53.

Cook, E. R., K. R. Briffa, and P. D. Jones (1994), Spatial regression methods in dendroclimatology: A review and comparison of 2 techniques, Int. J. Climatol., 14, 379-402, doi:10.1002/joc.3370140404.

Cook, E. R., K. R. Briffa, D. M. Meko, D. A. Graybill, and G. Funkhouser (1995), The segment length curse in long tree-ring chronology development for paleoclimatic studies, Holocene, 5, 229-237, doi:10.1177/ 095968369500500211.
Cook, E. R., C. A. Woodhouse, C. M. Eakin, D. M. Meko, and D. W. Stahle (2004), Long-term aridity changes in the western United States, Science, 306, 1015-1018, doi:10.1126/science.1102586.

Dai, A., K. E. Trenberth, and T. Qian (2004), A global dataset of Palmer Drought Severity Index for 1870-2002: Relationship with soil moisture and effects of surface warming, J. Hydrometeorol., 5, 1117-1130, doi:10.1175/JHM-386.1.

Dansgaard, W. (1964), Stable isotopes in precipitation, Tellus, 16, 436-468.

Durbin, J., and G. S. Watson (1951), Testing for serial correlation in least squares regression, Biometrika, 38, 159-178.

Esper, J., U. Büntgen, D. C. Frank, D. Niervergelt, and A. Liebhold (2007a), 1200 years of regular outbreaks in alpine insects, Proc. $R$. Soc. London, Ser. B, 274, 671-679, doi:10.1098/rspb.2006.0191.

Esper, J., D. Frank, U. Büntgen, A. Verstege, J. Luterbacher, and E. Xoplaki (2007b), Long-term drought severity variations in Morocco, Geophys. Res. Lett., 34, L17702, doi:10.1029/2007GL030844.

Esper, J., R. Niederer, P. Bebi, and D. Frank (2008), Climate signal age effects: Evidence from young and old trees in the Swiss Engadin, For Ecol. Manage., 255, 3783-3789, doi:10.1016/j.foreco.2008.03.015.

Farquhar, G. D., J. R. Ehleringer, and K. T. Hubick (1989), Carbon isotope discrimination and photosynthesis, Annu. Rev. Plant Physiol., 40, 503-537, doi:10.1146/annurev.pp.40.060189.002443.

Frank, D., and J. Esper (2005), Characterization and climate response patterns of a high-elevation multi-species tree-ring network in the European Alps, Dendrochronologia, 22, 107-121, doi:10.1016/j.dendro.2005. 02.004 .

Frank, D., U. Büntgen, R. Bohm, M. Maugeri, and J. Esper (2007a), Warmer early instrumental measurements versus colder reconstructed temperatures: Shooting at a moving target, Quat. Sci. Rev., 26, 3298-3310, doi:10.1016/j.quascirev.2007.08.002.

Frank, D., J. Esper, and E. R. Cook (2007b), Adjustment for proxy number and coherence in a large-scale temperature reconstruction, Geophys. Res. Lett., 34, L16709, doi:10.1029/2007GL030571.

Friedrichs, D. A., U. Büntgen, D. C. Frank, J. Esper, B. Neuwirth, and J. Löffler (2008), Complex climate controls on 20th century oak growth in central-west Germany, Tree Physiol., 29, 39-51, doi:10.1093/treephys/ tpn003.

Fritts, H. C. (1976), Tree Rings and Climate, Academic, London, U. K

Gagen, M., D. McCarroll, N. J. Loader, L. Robertson, R. Jalkanen, and K. J. Anchukaitis (2007), Exorcising the "segment length curse": Summer temperature reconstruction since AD 1640 using non-detrended stable carbon isotope ratios from pine trees in northern Finland, Holocene, 17, 435-446, doi:10.1177/0959683607077012.

Ghil, M., et al. (2002), Advanced spectral methods for climatic time series, Rev. Geophys., 40(1), 1003, doi:10.1029/2000RG000092.

Guiot, J. (1991), The bootstrapped response function, Tree Ring Bull, 51, 39-41.

Hilasvuori, E., F. Berninger, E. Sonninen, H. Tuomenvirta, and H. Jungner (2009), Stability of climate signal in carbon and oxygen isotope records and ring width from Scots pine (Pinus sylvestris L.) in Finland, J. Quat. Sci., doi:10.1002/jqs. 1260 .

Holmes, R. L. (1983), Computer-assisted quality control in tree-ring dating and measurements, Tree Ring Bull, 43, 69-78.

Kress, A., M. Saurer, U. Büntgen, K. Treydte, H. Bugmann, and R. T. W. Siegwolf (2009a), Summer temperature dependency of larch budmoth outbreaks revealed by Alpine tree-ring isotope chronologies, Oecologia, 160, 353-365, doi:10.1007/s00442-009-1290-4.

Kress, A., G. H. F. Young, M. Saurer, N. J. Loader, R. T. W. Siegwolf, and D. McCarroll (2009b), Stable isotope coherence in the earlywood and latewood of tree-line conifers, Chem. Geol., 268, 52-57, doi:10.1016/j. chemgeo.2009.07.008.

Leavitt, S. W., and A. Long (1988), Stable carbon isotope chronologies from trees in the southwestern United States, Global Biogeochem. Cycles, 2, 189-198, doi:10.1029/GB002i003p00189.

Lee, T. C. K., F. W. Zwiers, and M. Tsao (2008), Evaluation of proxybased millennial reconstruction methods, Clim. Dyn., 31, 263-281, doi:10.1007/s00382-007-0351-9.

Leuenberger, M. (2007), To what extent can ice core data contribute to the understanding of plant ecological developments of the past?, in Stable Isotopes as Indicators of Ecological Change, edited by T. E. Dawson and R. T. W. Siegwolf, pp. 211-233, Elsevier Acad., London.

Loader, N. J., et al. (2008), Multiple stable isotopes from oak trees in southwestern Scotland and the potential for stable isotope dendroclimatology in maritime climatic regions, Chem. Geol., 252, 62-71, doi:10.1016/j. chemgeo.2008.01.006. 
Mann, M. E., and J. M. Lees (1996), Robust estimation of background noise and signal detection in climatic time series, Clim. Change, 33 , 409-445, doi:10.1007/BF00142586.

McCarroll, D., and N. J. Loader (2004), Stable isotopes in tree rings, Quat. Sci. Rev., 23, 771-801, doi:10.1016/j.quascirev.2003.06.017.

McCarroll, D., and F. Pawellek (2001), Stable carbon isotope ratios of Pinus sylvestris from northern Finland and the potential for extracting a climate signal from long Fennoscandian chronologies, Holocene, 11, 517-526, doi:10.1191/095968301680223477.

Mitchell, T. D., and P. D. Jones (2005), An improved method of constructing a database of monthly climate observations and associated highresolution grids, Int. J. Climatol., 25, 693-712, doi:10.1002/joc.1181.

Moser, L., P. Fonti, U. Büntgen, J. Esper, J. Luterbacher, J. Franzen, and D. Frank (2010), Timing and duration of European larch growing season along altitudinal gradients in the Swiss Alps, Tree Physiol., 30(2), 225-233, doi:10.1093/treephys/tpp108.

Oberhuber, W., and W. Kofler (2002), Dendroclimatological spring rainfall reconstruction for an inner Alpine dry valley, Theor. Appl. Climatol., 71, 97-106, doi:10.1007/s704-002-8210-8.

Pauling, A., J. Luterbacher, C. Casty, and H. Wanner (2006), Five hundred years of gridded high-resolution precipitation reconstructions over Europe and the connection to large-scale circulation, Clim. Dyn., 26, 387-405, doi: $10.1007 / \mathrm{s} 00382-005-0090-8$.

Paulsen, J., and C. Körner (2001), GIS-analysis of tree-line elevation in the Swiss Alps suggests no exposure effect, J. Veg. Sci., 12, 817-824, doi: $10.2307 / 3236869$

Raffalli-Delerce, G., V. Masson-Delmotte, J. L. Dupouey, M. Stievenard, N. Breda, and J. M. Moisselin (2004), Reconstruction of summer droughts using tree-ring cellulose isotopes: A calibration study with living oaks from Brittany (western France), Tellus, Ser. B, 56, 160-174, doi:10.1111/j.1600-0889.2004.00086.x.

Raible, C. C., et al. (2006), Climate variability-observations, reconstructions, and model simulations for the Atlantic-European and Alpine region from 1500-2100 AD, Clim. Change, 79, 9-29, doi:10.1007/ s10584-006-9061-2.

Reynolds-Henne, C. E., R. T. W. Siegwolf, K. S. Treydte, J. Esper, S. Henne, and M. Saurer (2007), Temporal stability of climate-isotope relationships in tree rings of oak and pine (Ticino, Switzerland), Global Biogeochem. Cycles, 21, GB4009, doi:10.1029/2007GB002945.

Roden, J. S., G. Lin, and J. R. Ehleringer (2000), A mechanistic model for interpretation of hydrogen and oxygen isotope ratios in tree-ring cellulose, Geochim. Cosmochim. Acta, 64, 21-35, doi:10.1016/S0016-7037 (99)00195-7.

Rozanski, K., L. Arguas-Arguas, and R. Gonfiantini (1993), Isotopic patterns in modern global precipitation, in Climate Change in Continental Isotope Records, Geophys. Monogr. Ser., 78, pp. 1-36, AGU, Washington, D. C.

Saurer, M., and R. Siegwolf (2004), Pyrolysis techniques for oxygen isotope analysis of cellulose, in Handbook of Stable Isotope Analytical Techniques, edited by T. E. Dawson and R. T. W. Siegwolf, pp. $497-$ 508, Elsevier, New York.

Saurer, M., U. Siegenthaler, and F. H. Schweingruber (1995), The climatecarbon isotope relationship in tree-rings and the significance of site conditions, Tellus, Ser. B, 47, 320-330, doi:10.1034/j.1600-0889.47. issue 3.4.x

Saurer, M., S. Borella, and M. Leuenberger (1997a), $\delta^{18} \mathrm{O}$ of tree rings of beech (Fagus silvatica) as a record of $\delta^{18} \mathrm{O}$ of the growing season precipitation, Tellus, Ser. B, 49, 80-92, doi:10.1034/j.1600-0889.49.issue1.6.x.

Saurer, M., K. Aellen, and R. Siegwolf (1997b), Correlating $\delta^{13} \mathrm{C}$ and $\delta^{18} \mathrm{O}$ in cellulose of trees, Plant Cell Environ., 20, 1543-1550, doi:10.1046/ j.1365-3040.1997.d01-53.x.
Saurer, M., P. Cherubini, C. E. Reynolds-Henne, K. S. Treydte, W. T. Anderson, and R. T. W. Siegwolf (2008), An investigation of the common signal in tree ring stable isotope chronologies at temperate sites, J. Geophys. Res., 113, G04035, doi:10.1029/2008JG000689.

Seager, R., N. Graham, C. Herweijer, A. L. Gordon, Y. Kushnir, and E. Cook (2007), Blueprints for Medieval hydroclimate, Quat. Sci. Rev., 26, 2322-2336, doi:10.1016/j.quascirev.2007.04.020.

Stokes, M. A., and T. L. Smiley (1968) An Introduction to Tree-Ring Dating (reprinted 1996), Univ. of Ariz. Press, Tucson.

Thornthwaite, C. W. (1948), An approach toward a rational classification of climate, Geogr. Rev., 38, 55-94, doi:10.2307/210739.

Touchan, R., K. J. Anchukaitis, D. M. Meko, S. Attalah, C. Baisan, and A. Aloui (2008), Long term context for recent drought in northwestern Africa, Geophys. Res. Lett., 35, L13705, doi:10.1029/2008GL034264.

Treydte, K. S., G. H. Schleser, F. H. Schweingruber, and M. Winiger (2001), The climatic significance of $\delta^{13} \mathrm{C}$ in subalpine spruces (Lötschental, Swiss Alps), Tellus, Ser. B, 53, 593-611, doi:10.1034/j.1600-0889.2001. 530505.x.

Treydte, K. S., et al. (2006), The twentieth century was the wettest period in northern Pakistan over the past millennium, Nature, 440, 1179-1182, doi:10.1038/nature04743.

Treydte, K., et al. (2007), Signal strength and climate calibration of a European tree-ring isotope network, Geophys. Res. Lett., 34, L24302, doi:10.1029/2007GL031106.

van der Schrier, G., K. R. Briffa, P. D. Jones, and T. J. Osborn (2006), Summer moisture variability across Europe, J. Clim., 19, 2818-2834, doi:10.1175/JCLI3734.1.

van der Schrier, G., D. Efthymiadis, K. R. Briffa, and P. D. Jones (2007), European Alpine moisture variability for 1800-2003, Int. J. Climatol., 27, 415-427, doi:10.1002/joc.1411.

Wigley, T. M. L., K. R. Briffa, and P. D. Jones (1984), On the average value of correlated time series, with applications in dendroclimatology and hydrometeorology, J. Appl. Meteorol., 23, 201-213, doi:10.1175/ 1520-0450(1984)023<0201:OTAVOC $>2.0 . \mathrm{CO} ; 2$

Wilks, D. S. (2006), Statistical Methods in the Atmospheric Sciences, 2nd ed., 627 pp., Academic.

Wilson, R. J. S., B. H. Luckman, and J. Esper (2005), A 500 year dendroclimatic reconstruction of spring-summer precipitation from the lower Bavarian Forest region, Germany, Int. J. Climatol., 25, 611-630, doi:10.1002/joc. 1150 .

Yakir, D., M. J. DeNiro, and J. E. Ephrath (1990), Effects of water-stress on oxygen, hydrogen and carbon isotope ratios in two species of cotton plants, Plant Cell Environ., 13, 949-955, doi:10.1111/j.1365-3040.1990. tb01985.x.

Young, G. H. F., D. McCarroll, N. J. Loader, and A. J. Kirchhefer (2010), A 500-year record of summer near-ground solar radiation from tree-ring stable carbon isotopes, Holocene, 20(3), 315-324, doi:10.1177/ 0959683609351902.

H. Bugmann, Forest Ecology, Department of Environmental Sciences, ETH Zurich, CH-8092 Zürich, Switzerland.

J. Esper, Department of Geography, Johannes Gutenberg University Mainz, D-55099 Mainz, Germany.

D. C. Frank, Swiss Federal Institute for Forest, Snow, and Landscape Research, Zürcherstr. 111, CH-8903 Birmensdorf, Switzerland.

A. Kress, M. Saurer, and R. T. W. Siegwolf, Paul Scherrer Institut, CH-5232 Villigen PSI, Switzerland. (matthias.saurer@psi.ch) 